\title{
Micropropagation of Physalis species with economic potential
}

\author{
Luciana Sabini da Silva ${ }^{1}$, Fabíola Villa ${ }^{*} \mathbb{D}$, Daniel Fernandes da Silva ${ }^{1}$, Edvan Costa da Silva $a^{1}$ \\ Giovana Ritter ${ }^{1}$, Tatiane Eberling ${ }^{1}$ \\ $10.1590 / 0034-737 X 202168060003$
}

\begin{abstract}
The objective of this work was to evaluate asepsis protocols, composition and concentration of culture media in the in vitro establishment of three physalis species. In experiment I, seeds of 3 species were used $\mathrm{x} 3$ asepsis protocols. In experiment II, 3 culture media and explants 3 species were used. In experiment III, explants of 2 species $x 4$ concentrations of MS culture medium were used. In experiment IV, explants of 2 species x 4 sucrose concentrations were used. For experiments II, III and IV after 30 days were evaluated some phytotechnical parameters. The experimental design was completely randomized, in a $3 \times 3$ (experiments I and II) and 2 x 4 (experiments III and IV) factorial scheme. Protocols II and III were appropriate for P. peruviana germination, and I and III for P. minima, the three protocols were efficient for controlling fungi and bacteria. The MS is the most suitable for the in vitro establishment of three species. The culture medium at $100 \%$ concentration obtained better values in the in vitro development parameters evaluated for the species $P$. peruviana and P. minima. Sucrose concentrations close to 50 and $20 \mathrm{~g} \mathrm{~L}^{-1}$ favored the establishment of $P$. peruviana and P. minima.
\end{abstract}

Keywords: Physalis sp.; in vitro culture; asepsis; culture media; sucrose.

\section{INTRODUCTION}

Physalis is considered an exotic fruit with great economic potential, due to its adaptation to different Brazilian edaphoclimatic conditions. Its presence in supermarkets and local markets shows a trend of consumption by the population. Because it has high added value, fruit production is an alternative for small products that constitute the highest income per production area (Negri et al., 2016). Due to the potential of scientific interest it has increased in order to improve the production of culture, these show that the conditions for exploration for internal consumption and export (Chaves et al, 2005).

Asexual propagation is the main form of physalis multiplication, since this fruit has a large amount of seeds and a high germination rate, however it provides plantlets with high genetic variability, resulting in plants with different growth, vigor, performance and production of fruits, characteristics that are not interesting for commercial orchards (Oliveira et al., 2013). Tissue culture proposes obtaining large-scale plants, phytosanitary quality and high genetic fidelity. Among the challenges of this technique is mastering the various stages such as establishment and multiplication in vitro. (Mascarenhas et al., 2019).

The success of in vitro multiplication depends on the composition of the culture medium, which consists of essential elements for the growth of plants such as minerals, vitamins and carbohydrate source. These substances act as an energy source, provide control of tissue growth and regulate development in vitro. One of the ways to control these responses is through the concentration of macro and micronutrients that make up the culture media. (Oliveira et al., 2013a).

There are researches carried out by authors such as Chaves et al. (2005), Mascarenhas et al. (2019) with the

\footnotetext{
Submitted on August $26^{\text {th }}, 2020$ and accepted on February 14t $t^{\text {h }}, 2021$.

${ }^{1}$ Programa de Pós-Graduação em Agronomia (PPGA), Universidade Estadual do Oeste do Paraná, Marechal Cândido Rondon, Paraná, Brazil. fvilla2003@hotmail.com; luciana.sabini@hotmail.com; daniel_eafi@yahoo.com.br; edvan_costa@outlook.com; rittergio@hotmail.com; tatiane_eberling @ hotmail.com

*Corresponding author: fvilla2003@hotmail.com
} 
main commercial species ( $P$. peruviana), but data are missing with the other species that have economic potential and that, because they have different morphoanatomical characteristics (Silva et al., 2015), genotypes may respond differently to in vitro processes (Costa et al., 2015). These characteristics are complex and may indicate differences in nutritional needs, concentration of growth regulators, site of excision, type of tissue and genotype and consequently interfere in the multiplication rate in vitro cultivation (Mascarenhas et al., 2019).

Considering the complexity of the micropropagation steps that involve several factors, adjustments to the in vitro multiplication protocols that already exist for the different Physalis species are necessary, so this study aimed to evaluate protocols of asepsis, composition and concentration of culture media in the establishment and multiplication of Physalis species in vitro.

\section{MATERIAL AND METHODS}

\section{Experiment I}

The Physalis seeds used in this experiment were from ripe fruits collected in the, Germplasm Bank kept in the West State University of Paraná (Unioeste), Campus Marechal Cândido Rondon (PR). The species (Physalis peruviana, $P$. ixocarpa e $P$. minima) were properly identified and are categorized at the Unioeste's Herbarium. (HUNOP, Campus Cascavel).

After the withdrawal of fruits' seeds and the identification according to the species, they were taken to the Biotechnology Laboratory of the Pontifical Catholic University of Paraná (PUCPR), Campus Toledo (PR).

When received in the laboratory, the seeds of the three species (Physalis peruviana, P. ixocarpa e P. minima) were immediately taken to the laminar flow chamber BIOSEG 09 model, washed with distilled water and displayed in the asepsis protocols by immersion in: $\mathrm{I}=$ solution Tween 20 by $5^{\prime}+70 \%$ alcohol (A70) by $30^{\prime \prime}+$ Sodium hypochlorite $(\mathrm{NaClO})$ by $3^{\prime}, \mathrm{II}=\mathrm{A} 70$ by $30 "+$ $\mathrm{NaClO}$ by $3^{\prime}, \mathrm{III}=\mathrm{A} 70$ by $3^{\prime}+\mathrm{NaClO}$ by $10^{\prime}$. After the procedures, the seeds were washed four times in distilled water and autoclaved

After the sanitization, 5 seeds were allocated by glass bottle, with a total capacity of $300 \mathrm{~mL}$ volum, containing $25 \mathrm{~mL}$ of media culture MS (Murashige \& Skoog, 1962), added to $30 \mathrm{~g} \mathrm{~L}^{-1}$ of sucrose, $6 \mathrm{~g} \mathrm{~L}^{-1}$ of agar (Himedia ${ }^{\circledR}$ ) and $\mathrm{pH}=5,8$, adjusted before autoclaving. During 30 days, the fungal and bacterian contamination existent at every 4 days was evaluated.

The experimental outline used was completely randomized, in factorial scheme $3 \times 3$ [asepsis methods $\mathrm{x}$ Physalis peruviana, $P$. ixocarpa e P. minima]. Containing 5 repetitions, 1 bottle ( $500 \mathrm{ml}$ capacity) for repetition and 5 seeds of a species by bottle.

\section{Experiment II}

This experiment consisted of three medium cultures [MS, Knudson (Knudson, 1946), WPM (Lloyd \& McCown, 1981)] and three species of physalis (Physalis peruviana, P. minima e $P$. ixocarpa). The culture media were added of $30 \mathrm{~g} \mathrm{~L}^{-1}$ of sucrose $6 \mathrm{~g} \mathrm{~L}^{-1}$ of agar (Himedia ${ }^{\circledR}$ ) and $\mathrm{pH}=5.8$, adjusted before autoclaving.

The experimental outline used completely randomized, in factorial scheme $3 \times 3$ [culture media $\times$ physalis species], containing 5 repetitions, 1 bottle (500 ml capacity) for repetition and 5 explants of a species by bottle.

\section{Experiment III}

After the experiment II analysis, the culture media that presented proper characteristics for the establishment of the in vitro physalis species was defined. So, the experiment III was constituted by 4 concentrations of medium MS (0, 50, 75 e 100\%) and two physalis species (P. peruviana e $P$. minima). The culture media were added of $30 \mathrm{~g} \mathrm{~L}^{-1}$ of sucrose $6 \mathrm{~g} \mathrm{~L}^{-1}$ of agar (Himedia ${ }^{\circledR}$ ) and $\mathrm{pH}=$ 5.8 , adjusted before autoclaving.

The experimental outline used in this experiment was completely randomized, in factorial scheme $4 \times 2$ [concentrations of culture media $\mathrm{x}$ physalis species]. Containing 5 repetitions, 1 bottle $(500 \mathrm{ml}$ capacity) for repetition and 5 explants of a species by bottle.

\section{Experiment IV}

In this experiment four concentrations of sucrose were evaluated, these being $0,15,30,60 \mathrm{~g} \mathrm{~L}^{-1}$, for two species of physalis (P. peruviana e P. minima). The concentration of $100 \%$ of culture media (MS) was used, plus $6 \mathrm{~g} \mathrm{~L}^{-1}$ of agar $\left(\right.$ Himedia $\left.^{\circledR}\right)$ and $\mathrm{pH}=5.8$, adjusted before autoclaving.

The experimental outline was done entirely by chance, in factorial scheme $4 \times 2$ [concentrations of sucrose $\mathrm{x}$ species of physalis], containing 5 repetitions, 1 bottle (500 $\mathrm{ml}$ capacity) for repetition and 5 explants of a species by bottle.

For all the experiments, the bottles were covered with aluminum paper and autoclaved at $121^{\circ} \mathrm{C}$ and $1.2 \mathrm{~atm}$ of pression, during 20'. After the autoclaving, they were sealed with plastic film of PVC, in order to avoid contaminations and kept in wooden shelves $(45 \times 30 \mathrm{~cm})$, in a growth room, with photoperiod of $16 \mathrm{~h}$ light and temperature $\pm 24^{\circ} \mathrm{C}$.

In the experiments II, III and IV were used explants of pre-established plants in vitro from seeds were used. The explants from the third pricking-out were excised with the help of a scalpel, in laminar flow chamber in petri-dishes. These contained $1.5 \mathrm{~cm}$ of lenght, two opposite axillary buds and a pair of leaves.

After 30 days of the building of the experiments (II,III and IV), the number of plantlets sprouts, leaves and roots 
were evaluated. With the aid of a ruler, the lenght of the bigger root $(\mathrm{cm})$ and the total of the plant $(\mathrm{cm})$ were evaluated and by weighing on an analytical balance the fresh and dry plantlets biomass (g) was also evaluated. To obtain the dry plantlets biomass, they were put in white paper bags properly identified and taken to the to the forced ventilation oven at $65^{\circ} \mathrm{C}$ for $48 \mathrm{~h}$.

The data obtained in all experiments was tabbed and the test of normality Shapiro-Wilk was applied. Afterwards, they were submitted to the analysis of variance and regression analysis for quantitative data, at $5 \%$ of error probability, being changed into $(\mathrm{Y}+1.0) 0.5$, whenever necessary. For the results analysis, the Sisvar was used (Ferreira, 2011).

\section{RESULTS AND DISCUSSION}

\section{Experiment I}

In Table 1 germination data (\%), fungal and bacterial contamination (\%) and total contaminaion (\%) in seeds of physalis species is presented, where the significant effect for the first factor and the statistical difference for the species Physalis peruviana e $P$. minima was verified.

Better results in germination (\%) in vitro were observed for $P$. peruviana, when using protocols II and
III. For $P$. minima seeds, the highest germination percentage occurred when using protocols I and III; Protocol II showed a lower germination rate, a fact that may be related to a lower amount of reagents and exposure time. For P. ixocarpa, there was no statistical difference for germination between the protocols used. for all species when protocol III is used, good results are observed, which makes it possible to standardize the procedure with good results for the germination parameter.

Studies carried out by Chaves et al. (2005) showed that the rate of germination of $P$. peruviana was reduced, when solutions with calcium hypochlorite in seed asepsis were used, probably due to the high fungic contamination. The diferences in the germination rate of seeds among the distinct works were caused by the combination of several substances of asepsis. When the $\mathrm{NaClO}$ for asepsis was used, Pinheiro et al. (2016) noticed reduction in the fungic contamination, increase in the germinative potential in Cedrela fissilis seeds.

The low rate of total contamination (\%) and all efficiency of protocols for this factor can be explained by the sequence of products used in seeds' asepsis. Besides that, it is taken for granted that there is a

Table 1: Germination (\%) in vitro seeds of physalis species (Physalis peruviana, P. ixocarpa and P. minima), fungal contamination $(\%)$ and bacterial contamination (\%) in three asepsis protocols

\begin{tabular}{|c|c|c|c|}
\hline \multirow{3}{*}{ Protocolsasepsis } & \multicolumn{3}{|c|}{ In vitro seed germination $(\%) * *$} \\
\hline & \multicolumn{3}{|c|}{ Species of Physalis } \\
\hline & P.peruviana & P. ixocarpa & P. minima \\
\hline I & $44.0 \mathrm{bB}^{*}$ & $52.0^{\mathrm{ns}}$ & $88.0 \mathrm{aA}$ \\
\hline II & $72.0 \mathrm{a}$ & $36.0^{\mathrm{ns}}$ & $40.0 \mathrm{~b}$ \\
\hline III & $88.0 \mathrm{aA}$ & $32.0^{\mathrm{ns}}$ & $100.0 \mathrm{aA}$ \\
\hline \multirow[t]{2}{*}{$\mathrm{CV}(\%)$} & \multicolumn{2}{|c|}{22.57} & \\
\hline & \multicolumn{3}{|c|}{ Fungal contamination $(\%) * *$} \\
\hline I & $5.0^{\mathrm{ns}}$ & $15.0^{\mathrm{ns}}$ & $30.2^{\text {ns }}$ \\
\hline II & $15.0^{\mathrm{ns}}$ & $5.0^{\mathrm{ns}}$ & $31.0^{\mathrm{ns}}$ \\
\hline III & $5.0^{\mathrm{ns}}$ & $38.0^{\mathrm{ns}}$ & $8.0^{\mathrm{ns}}$ \\
\hline \multirow[t]{2}{*}{$\mathrm{CV}(\%)$} & \multicolumn{2}{|c|}{40.48} & \\
\hline & \multicolumn{3}{|c|}{ Bacterial contamination $(\%) * *$} \\
\hline I & $2.45^{\mathrm{ns}}$ & $2.88^{\mathrm{ns}}$ & $2.59^{\mathrm{ns}}$ \\
\hline II & $2.45^{\mathrm{ns}}$ & 2.45 ns & 2.45 ns \\
\hline III & $2.45^{\mathrm{ns}}$ & $2.45^{\mathrm{ns}}$ & $2.88^{\mathrm{ns}}$ \\
\hline \multirow[t]{2}{*}{$\mathrm{CV}(\%)$} & \multicolumn{2}{|c|}{23.54} & \\
\hline & \multicolumn{3}{|c|}{ Total contamination $(\%)$} \\
\hline I & $3.32^{\mathrm{ns}}$ & $4.63^{\mathrm{ns}}$ & $5.23^{\mathrm{ns}}$ \\
\hline II & $4.37^{\mathrm{ns}}$ & $3.32^{\mathrm{ns}}$ & $5.41^{\mathrm{ns}}$ \\
\hline III & $3.32^{\mathrm{ns}}$ & $6.16^{\mathrm{ns}}$ & $3.93^{\mathrm{ns}}$ \\
\hline
\end{tabular}
probability of error. $\mathrm{ns}=$ not significant. $* *$ Data transformed to square root of $\mathrm{x}+1$. 
combination between chlorine and the membrane protein of microorganisms which form toxic compounds leading to the inhibition of essential enzymes for survival (Machado \& Fernandes, 2018). The 70\% alcohol is pointed out as a disinfectant and according to Tomazzi et al. (2019) when it is present at this concentration it evaporates slowly potentializing its action of denaturation of proteins in microbial cells when in contact with microorganisms.

\section{Experiment II}

In Table 2, it is observed that the number of regenerated seedlings, when compared to the culture media in Physalis peruviana there was no statistical difference and in P. ixocarpa there was a greater number of regenerated when in MS medium. In P. minima, there was the lowest number of seedlings regenerated when in medium Knudson.

When the sprouts are analysed, for P.minima there was no difference between the WPM and MS medium. This variable had the same behavior for $P$. peruviana $e P$. ixocarpa, being the MS medium, the one that provided a greater number of sprouts for the species.

The MS medium is more concentrated in nitrogen in relation to other studied mediums, fact that influences in the synthesis of endogenous cytokinins, resulting in a number of sprous by species nodal segment as verified in the presente work (Jesus et al., 2010).

Table 2: Number of regenerated plantlets (NPR), number of sprouts (NB), number of leaves (NF) and length of plantlets (CP) of physalis species, in culture media

\begin{tabular}{|c|c|c|c|}
\hline \multirow{3}{*}{ Physalis species } & \multicolumn{3}{|c|}{ Culture medium } \\
\hline & Knudson & MS & WPM \\
\hline & \multicolumn{3}{|c|}{ Number of regenerated plants } \\
\hline Physalis peruviana & $4.20 \mathrm{aA} *$ & $5.00 \mathrm{aA}$ & $5.00 \mathrm{aA}$ \\
\hline Physalis ixocarpa & $0.01 \mathrm{bB}$ & $5.00 \mathrm{aA}$ & $0.01 \mathrm{bB}$ \\
\hline Physalis minima & $0.80 \mathrm{bB}$ & $4.20 \mathrm{aA}$ & $4.40 \mathrm{aA}$ \\
\hline \multirow[t]{2}{*}{$\mathrm{CV}(\%)$} & \multicolumn{2}{|c|}{16.71} & \\
\hline & \multicolumn{3}{|c|}{ Number of shoots $* *$} \\
\hline Physalis peruviana & $1.17 \mathrm{abAB}$ & $1.33 \mathrm{bA}$ & $1.04 \mathrm{bB}$ \\
\hline Physalis ixocarpa & $1.00 \mathrm{bB}$ & $1.68 \mathrm{aA}$ & $1.00 \mathrm{bB}$ \\
\hline Physalis minima & $1.20 \mathrm{aB}$ & $1.53 \mathrm{aA}$ & $1.41 \mathrm{aA}$ \\
\hline \multirow[t]{2}{*}{$\mathrm{CV}(\%)$} & \multicolumn{2}{|c|}{10.03} & \\
\hline & \multicolumn{3}{|c|}{ Number of sheets $* *$} \\
\hline Physalis peruviana & $1.84 \mathrm{aB}$ & $2.41 \mathrm{bA}$ & $1.76 \mathrm{bB}$ \\
\hline Physalis ixocarpa & $1.00 \mathrm{bB}$ & $2.99 \mathrm{aA}$ & $1.00 \mathrm{aB}$ \\
\hline Physalis minima & $1.64 \mathrm{aC}$ & $3.03 \mathrm{aA}$ & $2.19 \mathrm{aB}$ \\
\hline \multirow[t]{2}{*}{$\mathrm{CV}(\%)$} & \multicolumn{2}{|c|}{16.70} & \\
\hline & \multicolumn{3}{|c|}{ Seedling length $(\mathrm{cm}) * *$} \\
\hline Physalis peruviana & $2.07 \mathrm{aB}$ & $3.17 \mathrm{aA}$ & $2.01 \mathrm{aB}$ \\
\hline Physalis ixocarpa & $1.00 \mathrm{cB}$ & $2.55 \mathrm{bA}$ & $1.00 \mathrm{bB}$ \\
\hline Physalis minima & $1.47 \mathrm{bC}$ & $2.89 \mathrm{abA}$ & $2.13 \mathrm{aB}$ \\
\hline \multirow[t]{2}{*}{$\mathrm{CV}(\%)$} & \multicolumn{2}{|c|}{14.12} & \\
\hline & \multicolumn{3}{|c|}{ Length of the largest root $(\mathrm{cm}) * *$} \\
\hline Physalis peruviana & $1.29 \mathrm{~ns}$ & $2.88 \mathrm{aA}$ & $1.10 \mathrm{~ns}$ \\
\hline Physalis ixocarpa & $1.00 \mathrm{~ns}$ & $1.43 \mathrm{c}$ & $1.00 \mathrm{~ns}$ \\
\hline Physalis minima & $1.23 \mathrm{~ns}$ & $2.07 \mathrm{bA}$ & $1.22 \mathrm{~ns}$ \\
\hline \multirow[t]{2}{*}{$\mathrm{CV}(\%)$} & \multicolumn{2}{|c|}{23.08} & \\
\hline & \multicolumn{3}{|c|}{ Fresh seedling biomass $(\mathrm{g})$} \\
\hline Physalis peruviana & $1.17 \mathrm{aB}$ & $1.62 \mathrm{aA}$ & $1.13 \mathrm{bB}$ \\
\hline Physalis ixocarpa & $1.00 \mathrm{bB}$ & $1.24 \mathrm{bA}$ & $1.00 \mathrm{bB}$ \\
\hline Physalis minima & $1.07 \mathrm{abC}$ & $1.61 \mathrm{aA}$ & $1.34 \mathrm{aB}$ \\
\hline $\mathrm{CV}(\%)$ & \multicolumn{3}{|c|}{8.68} \\
\hline
\end{tabular}

*Lower case letters differ statistically from each other in the column and upper case letters from the line, using the Tukey test, at $5 \%$ probability of error. $\mathrm{ns}=$ not significant. $* *$ Data transformed to square root of $\mathrm{x}+1$. 
When the number of leaves is analysed for the evaluated species, the MS medium was considered proper when compared to WPM e Knudson culture media. Oliveira et al. (2013a) obtained an average number of Physalis angulata in vitro leaves, similar to the one found in the present work.

A greater length of seedlings was verified in MS medium for the three species studied. Araujo et al. (2016) state that in addition to being rich in nitrogen, the MS medium also contains calcium four times more concentration than the other media, this is a structural component, responsible for the connection between pectins and groups of lipid acids, in addition, it acts as a signal, stimulating the production of auxin and cytokinin, endogenous hormones responsible for growth (Kerbauy, 2012).

Besides that, in works with fruit species in vitro, such as blackberry, pineapple and casserole, authors observed a good development having a greater number of leaves.sprouts and lenght of these plantlets, when propagated in a MS cultivation medium (Leitzke et al., 2010; Oliveira-Cauduro et al., 2016; Araujo et al., 2016).

When the fresh biomass was evaluated, the behavior was similar to the MS medium that presented better results for the three species, when compared to Knudson and WPM. These aspects show that culture media favors the assimilation of nutrients, fact that explains the better performance of plants in MS medium.

Table 3: Number of roots and dry biomass of the area $(\mathrm{g})$ for physalis species and culture media

\begin{tabular}{lcc}
\hline Species of Physalis & $\begin{array}{c}\text { Number } * * \\
\text { of roots }\end{array}$ & $\begin{array}{c}\text { Seedling } \\
\text { dry biomass (g) }\end{array}$ \\
\hline Physalis peruviana & $1.99 \mathrm{a}^{*}$ & $1.04 \mathrm{a}$ \\
Physalis ixocarpa & $1.41 \mathrm{~b}$ & $1.01 \mathrm{~b}$ \\
Physalis minima & $1.87 \mathrm{a}$ & $1.04 \mathrm{a}$ \\
\hline Culture media & \\
\hline WPM & $1.43 \mathrm{~b}$ & $1.02 \mathrm{~b}$ \\
Knudson & $1.43 \mathrm{~b}$ & $1.01 \mathrm{~b}$ \\
MS & 2.41 & $1.06 \mathrm{a}$ \\
\hline CV $(\%)$ & \multicolumn{2}{c}{24.91}
\end{tabular}

*Lower case letters differ statistically from each other in the column, using the Tukey test, at $5 \%$ probability of error. **Data transformed to square root of $\mathrm{x}+1$.

Table 4: Number of plantlets regenerated for physalis species

\begin{tabular}{lc}
\hline Species of Physalis & $\begin{array}{c}\text { Number of plantlets } \\
\text { regenerated }\end{array}$ \\
\hline Physalis minima & $2.34 \mathrm{a}^{*}$ \\
Physalis peruviana & $1.35 \mathrm{~b}$ \\
\hline $\mathrm{CV}(\%)$ & 12.91
\end{tabular}

*Lower case letters differ statistically from each other in the column, using the Tukey test, at $5 \%$ probability of error. $* *$ Data transformed to square root of $\mathrm{x}+1$.
The evaluations that did not present a significant interaction are presented in Table 3, being those, a number of roots and, dry seedling biomass. It is noticed that he number of roots was samller for $P$. ixocarpa, when compared to the other species and the same behavior occurs to dry shoot biomass.

The MS cultivation medium promoted a bigger quantity of roots, being superior to the Knudson e WPM, ones that did not differ statistically between them. The presence of the boron, which is in bigger quantity in the MS medium, promote synthesis of indolacetic acid (AIA) and acts translocation of natural auxin, promoting the rooting. The bigger dry biomass values were found in the MS medium that is more concentrated in salts and nutrients, being an important attribute of growth (Moschini et al., 2019).

\section{Experiment III}

The factor evaluated the number of regenerated plantlets that did not present interaction and because of that, it was separately evaluated in Table 4, where we can observe that $P$. minima had a greateer number of regenerated plantlets compared to $P$. peruviana.

The Figure 2A presents a number of sprouts of $P$. peruviana e P.minima in concentrations of the MS medium, we notice that both species had greater values of sprouts when in a medium at concentration of $100 \%$, growing in a linear manner. In Figure 2B, we can notice that the seedling lenght for $P$. minima obtained a linear growth according to the increase of the medium concentration, reaching its maximum value of approximately 3.0 $\mathrm{cm}$ in $100 \%$ of culture media. In P. peruviana it was noticed that there was no significant difference in the growth according to the variation of the medium culture.

For the number of leaves (Figura 2C), it is possible to verify that the species increased the quantity according to the increase of the concentration of the culture medium. The species Physalis minima, had its greater number of leaves in $100 \%$ of culture media, with approximately 7 leaves and the $P$. peruviana obtained at the maximun 3 leaves.

The phosphorus presents in the culture medium acts differently in the leaf expansion. The incorporation of this nutrient depends on the genotype of each species. Costa et al. (2015) observed that there was a greater number of leaves in the MS medium, however without statistical differences in MS medium with $50 \%$ of nitrate, working with hybrid basil, indicating that other factors can interfere in these characteristics.

The length of the larger root (Figure 2D) of P. peruviana did not obtain statistical difference when the concentration of the culture medium varied. However, the $P$. minima varied a little its length and had its greater value of approximately $1.5 \mathrm{~cm}$ at $100 \%$ of medium. 
According to Lemes et al. (2016), the plantlets present the need of low concentrations of nitrogen in the formation of roots and concentration of high levels of salts can affect negatively the development of roots. Therefore, the rooting can be related to each species' characteristics response to the in vitro stimuli.

Regarding the number of roots, there was no species $\mathrm{x}$ concentration of the culture medium. Therefore, only the
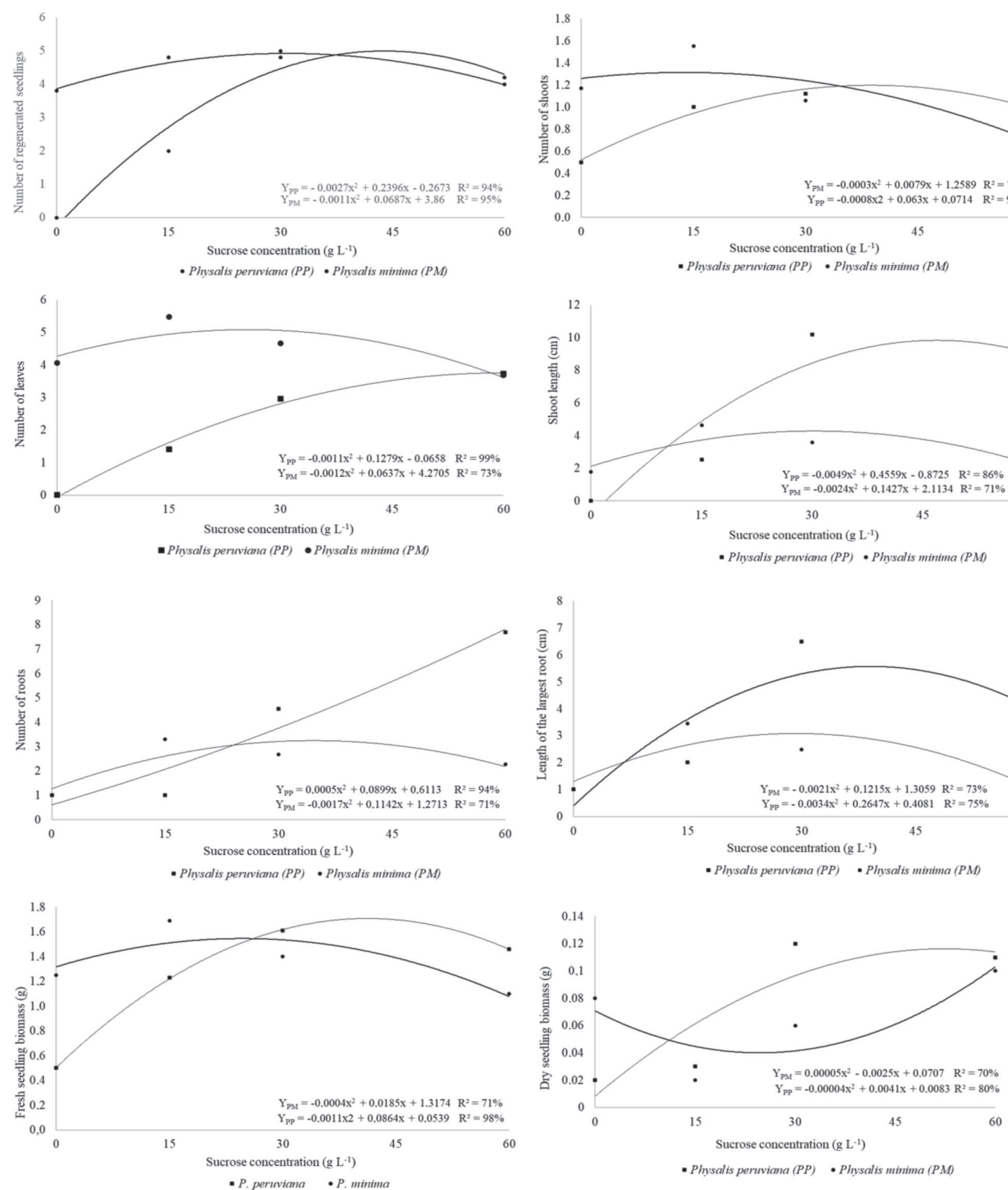

Figure 1: Number of regenerated plantlets $[A]$, number of sprout $[B]$, seedling length $(\mathrm{cm})[C]$, number of leaves [D], length of largest $\operatorname{root}(\mathrm{cm})[\mathrm{E}]$, number of roots $[\mathrm{F}]$, fresh seedling biomass $(\mathrm{g})[\mathrm{G}]$, dry seedling biomass $(\mathrm{g})[\mathrm{H}]$, as a function of sucrose concentration $\left(0,15,30,45,60 \mathrm{~g} \mathrm{~L}^{-1}\right)$.

Rev. Ceres, Viçosa, v. 68, n.6, p. 521-529, nov/dec, 2021

concentration of the culture medium $\mathrm{x}$ number of roots was evaluated (Figure 2E). It can be seen that the number of roots tended to grow, due to the presence of boron and other micronutrients that promote the synthesis of AIA (indolacetic acid) and the translocation of natural auxin, enabling rooting (Pasqual, 2001).

For fresh and dry seedling biomass, it was not observed any statistical difference between the concentra-
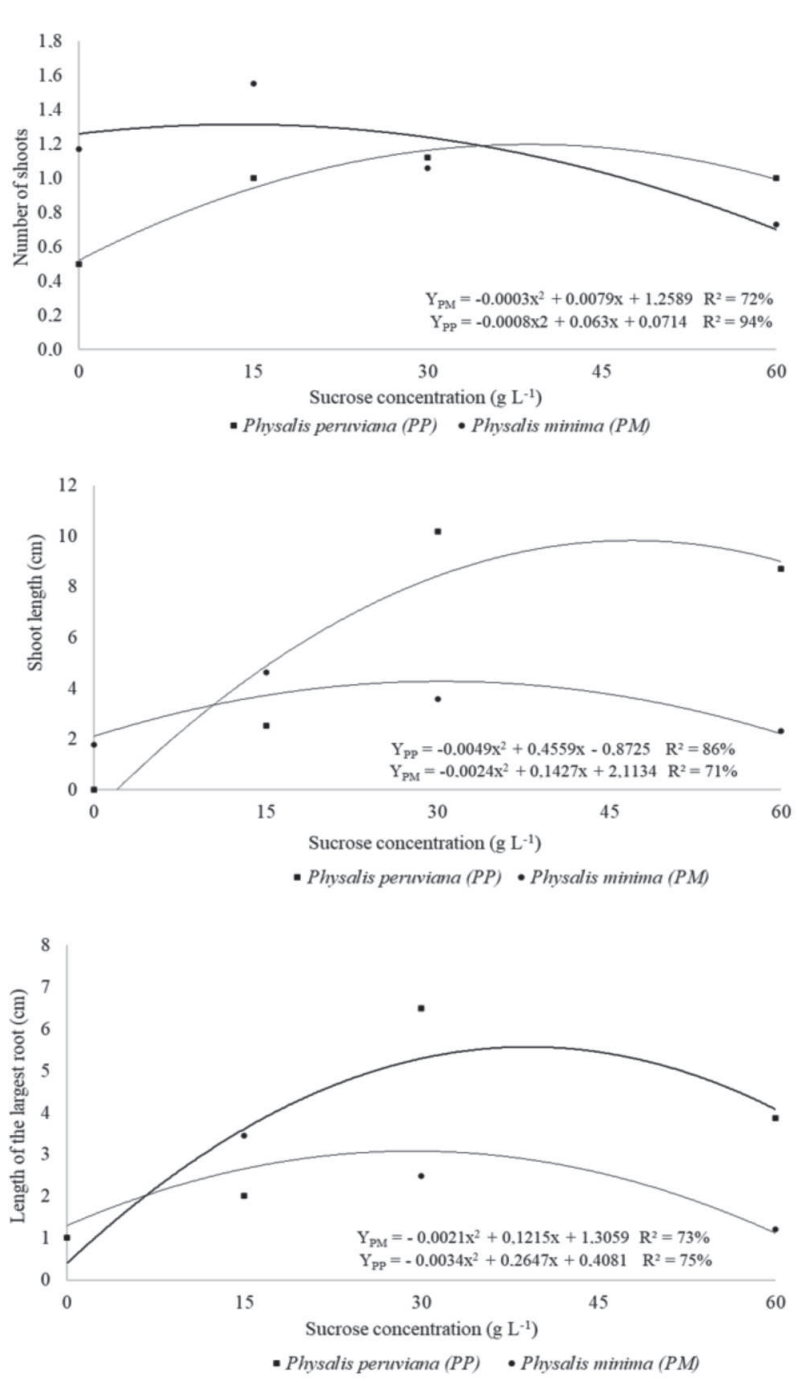

$B]$, seedling length $(\mathrm{cm})[C]$, number of leaves $[\mathrm{D}]$, length of largest
dry seedling biomass $(\mathrm{g})[\mathrm{H}]$, as a function of sucrose concentration

(n) 
tions for P. peruviana. For P. minima, greater values were found at $100 \%$ of culture media, having approximately 1.8 e $1.2 \mathrm{~g}$, respectively.

\section{Experiment IV}

In figure 1 the results found when physalis species $(P$. peruviana e $P$. minima) were submitted to the concentration of sucrose are shown.

It can be seen that the number of regenerated seedlings (Figure 1A), in P. peruviana, increased with increasing
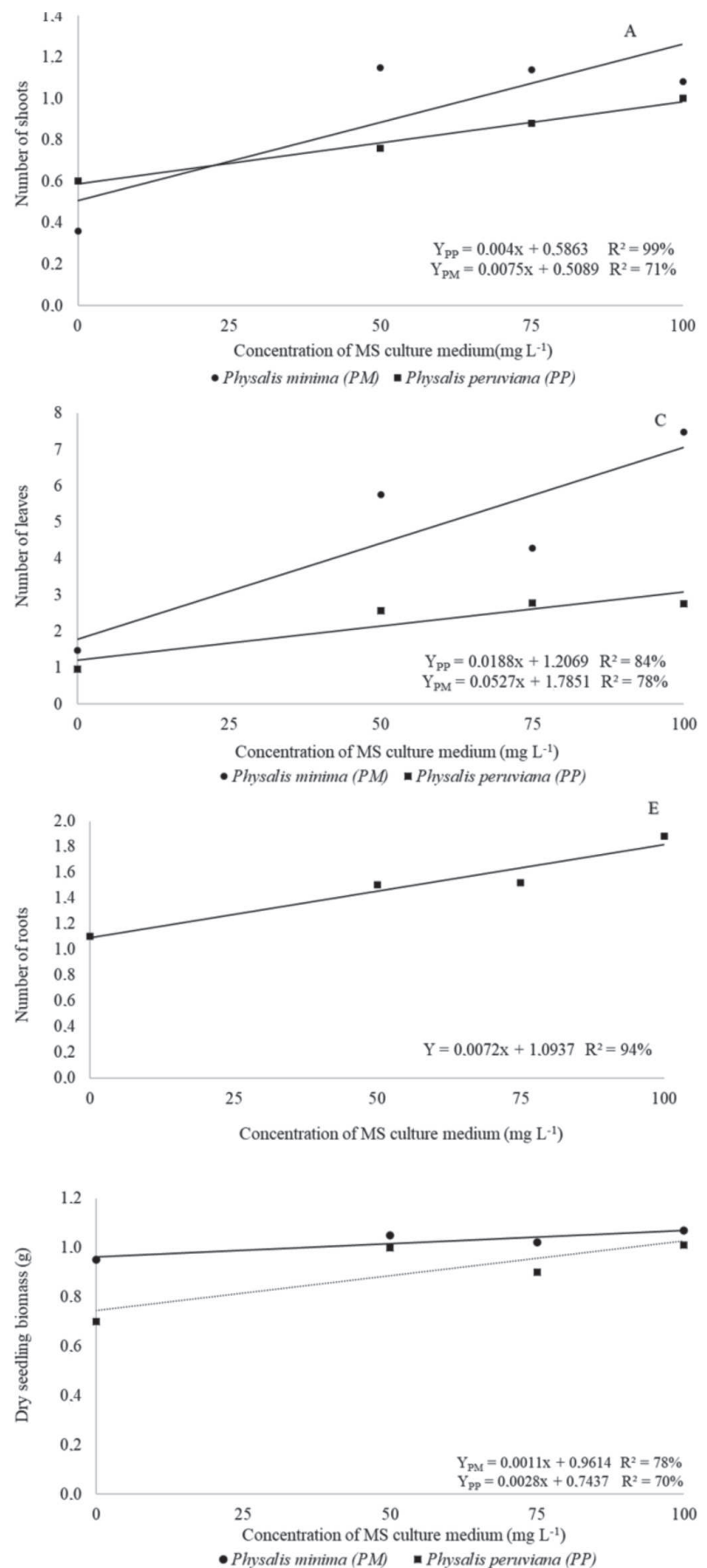

sucrose concentrations and peaked at $44 \mathrm{~g} \mathrm{~L}^{-1}$ with an average of 5,05 regenerated seedlings and after this concentration there was a fall in regeneration. For $P$. minimal the same trend was observed, this species reached its maximum point in $31 \mathrm{~g} \mathrm{~L}^{-1}$ of sucrose with an average of 4,9 plantlets.

When the number of sprouts was evaluated (Figure 1B), P. peruviana increased up to the concentration of 40 $\mathrm{g} \mathrm{L}^{-1}$ of sucrose, when it obtained the average value of approximately 1.5 sprouts. $P$. minima had its maximum
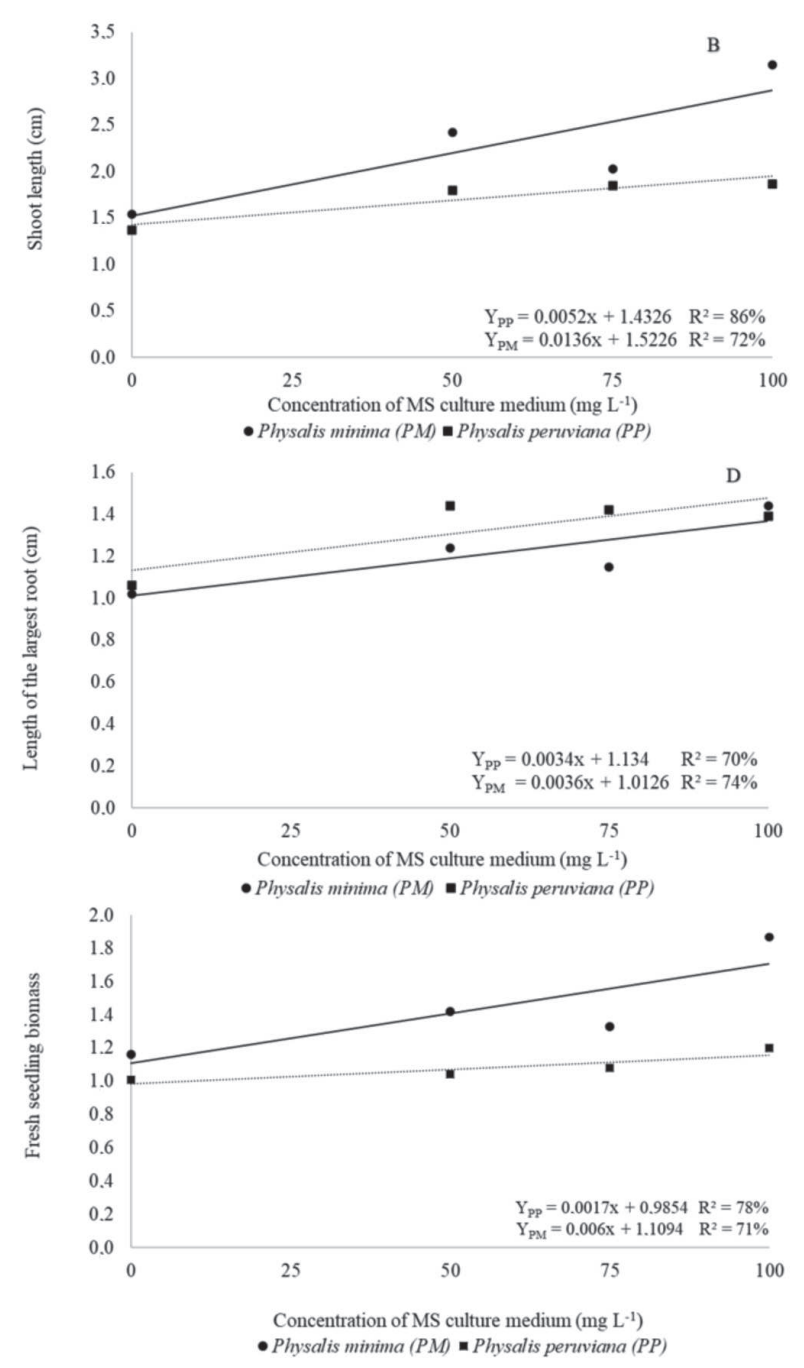

Figure 2: Shoot number [A], seedling length $(\mathrm{cm})[B]$, number of leaves [C], length of largest root $(\mathrm{cm})[\mathrm{D}]$, number of roots [E], fresh seedling biomass $(\mathrm{g})[\mathrm{F}]$, dry seedling biomass $(\mathrm{g})[\mathrm{G}]$, depending on the concentration of MS culture medium $(0,50,75$ and $100 \%)$. 
point at $15 \mathrm{~g} \mathrm{~L}^{-1}$ with 1.3 sprouts and decreased with the increase of sucrose concentration.

Studies carried out by Poothong et al. (2020) showed that the reduced sucrose in the concentrations of $1.5 \%$ and $3 \%$ in the medium MS, increased the number of sprouts for raspberry, however the length of sprouts was greater when sucrose was not added to the media culture.

The length of the seedling (Figure 1C) presented the greater average of explant growth (approximately $10 \mathrm{~cm}$ ) when used $45 \mathrm{~g} \mathrm{~L}^{-1}$ of sucrose for $P$. peruviana. In $P$. minima the greater average growth was approximately $5 \mathrm{~cm}$ at the concentration of $30 \mathrm{~g} \mathrm{~L}^{-1}$ of sucrose.

A concentration of $15 \mathrm{~g} \mathrm{~L}^{-1}$ favored a quantity of leaves of $P$. minima, that at this concentration, it reached the average value of approximately 5 leaves by explant. $P$. peruviana had the maximum value of leaves of 3.6 when used $60 \mathrm{~g} \mathrm{~L}^{-1}$ of sucrose

The excess of sucrose in the culture media can inhibit the chlorophyll synthesis and reduce the photosynthetic capacity of crops, besides that, due to the lack of $\mathrm{CO}_{2}$ in the cultivation in vitro, a process of photosynthesis does not normally occur, so the explant depends of a source of energy that possibilitates the normal activity of cells physiological functions promoting the development of explants (Ayub et al., 2019).

The number of roots and the length of the biggest root for P. minima were better at the concentration of $30 \mathrm{~g} \mathrm{~L}^{-1}$ of sucrose, obtaining the values of approximately 3.5 roots and $3.3 \mathrm{~cm}$. When $P$. peruviana was evaluated, the greater amount of roots was obtained when $60 \mathrm{~g} \mathrm{~L}^{-1}$ of sucrose was used, with approximately 8 roots for each explant and the biggest root length with $30 \mathrm{~g} \mathrm{~L}^{-1}$ having in average $6 \mathrm{~cm}$.

For the formation of roots, energy that can be from photosynthesis or from other source of sugar is necessary. The exogenous carbon in the culture medium influences in the differentiation and growth of tissues, induction and differentiation of tissues and organs induction and differentiation. According to Calvete et al. (2002), the sucrose stimulates the rhizogenesis in vitro and in its absence, there was no rooting in strawberry explants.

The fresh biomass had an increase up to $40 \mathrm{~g} \mathrm{~L}^{-1}$ for $P$. peruviana and $24 \mathrm{~g} \mathrm{~L}^{-1}$ for $P$. minima, after these values, there was a reduction in the seedling's weight. However, when the fresh biomass is evaluated, the greater value obtained for the species is at $60 \mathrm{~g} \mathrm{~L}^{-1}$ of sucrose, what indicates that at this concentration, less water accumulation and greater salts accumulation occured.

For most of the parameters analysed, $P$. minima had its development favored at low sucrose concentrations (between 15 and $30 \mathrm{~g} \mathrm{~L}^{-1}$ ) when compared to the values of P. peruviana (between 45 and $60 \mathrm{~g} \mathrm{~L}^{-1}$ ), what indicates that the species genotype presents distinct needs for its development.

\section{CONCLUSIONS}

The protocols II e III were adequated for the germination P. peruviana, and I and III for P. minima, the three protocols were efficient for the control of fungus and bacteria.

The sucrose concentrations close to $50 \mathrm{~g} \mathrm{~L}^{-1}$ favored the establishment of $P$. peruviana of approximately $20 \mathrm{~g}$ $\mathrm{L}^{-1}$ favored the establishment of $P$ minima.

The culture medium MS is the more indicated one for the in vitro establishment of $P$. peruviana, $P$. minima and P. ixocarpa.

The cultivation medium at the concentration of $100 \%$ obtained better values in the parameters of in vitro development evaluated for the species $P$. peruviana e $P$. minima.

\section{ACKNOWLEDGMENT}

To CAPES for granting a scholarship. There are no conflicts of interest.

\section{REFERENCES}

Araujo MCR, Chagas EA, Garcia MIR, Sobral Pinto ST, Chagas PC, Vendrame W, Mota Filho AB \& Souza OM (2016) Micropropagation of caçari under different nutritive culture media, antioxidants, and levels of agar and $\mathrm{pH}$. African Journal of Biotechnology, 15:1771-1780.

Ayub RA, Santos JN, Zanlorensi Junior LA, Silva DM, Carvalho TC \& Grimaldi F (2019) Sucrose concentration and volume of liquid medium on the in vitro growth and development of blackberry cv. Tupy in temporary immersion systems. Ciência e Agrotecnologia, 43:1-8.

Calvete EO, Kämpf NA \& Suzin M (2002) Concentração de sacarose no enraizamento in vitro de morangueiro. Horticultura Brasileira, 20:186-191.

Chaves AC, Schuch MW \& Erig AC (2005) Estabelecimento e multiplicação in vitro de Physalis peruviana L. Ciência \& Agrotecnologia, 29:1281-1287.

Costa ASM, Blank MFA, Silva JHS, Torres MF, Santos ONA \& Blank AF (2015) Multiplicação in vitro e indução de calos embriogênicos em híbrido de manjericão. Revista Scientia Plena, 11:1-13.

Ferreira DF (2011) Sisvar: a computer statistical analysis system. Ciência e Agrotecnologia, 35:1039-1042.

Jesus AMS, Carvalho SP, Villa F, Pasqual M \& Carvalho M (2010) Desenvolvimento in vitro de brotações de cafeeiro em diferentes meios de cultura e reguladores de crescimento de planta. Scientia Agraria, 11:431-436.

Kerbauy GB (2012) Fisiologia Vegetal. $2^{\text {nd }}$ ed. Rio de Janeiro, Guanabara Koogan. 431p.

Knudson L (1946) A new nutrient solution for germination of orchid seed. American Orchid Society Bulletin, 15:214-217.

Leitzke LN, Damiani CR \& Schuch MW (2010) Influência do meio de cultura, tipo e concentração de citocininas na multiplicação in vitro de amoreira-preta e framboeseira. Ciência e Agrotecnologia, 34:352-360.

Lemes CSR, Sorgato JC, Soares JS \& Rosa YBCJ (2016) Meios de cultivo e sacarose no crescimento inicial in vitro de Miltonia flavescens. Ciência Rural, 46:499-505. 
Lloyd G \& McCown B (1980) Commercially-feasible micropropagation of Mountain laurel, Kalmia latifolia, by use of shoot tip culture. International Plant Propagation Society Proceedings, 30:421-427.

Machado RGJ \& Fernandes DA (2018) Assepsia e germinação in vitro de Adenium obesum. Connection, 18:102-110.

Mascarenhas LMS, Santana JFR \& Brito AL (2019) Micropropagation of Physalis peruviana L. Pesquisa Agropecuária Tropical, 49:1-8.

Moschini BP, Cheng NC, Bispo DFA, Santos JLA, Pedrosa CE \& Peche PM (2019) Diagnose visual de potássio e ferro no crescimento inicial de mudas de Physalis ixocarpa L. Agropecuaria Científica no Semiárido, 15:315-323.

Murashige T \& Skoog FA (1962) A revised medium for rapid growth and bioassay with tobacco tissue culture. Physiologia Plantarum, 15:473-497.

Negri TC, Berni PRA \& Brazaca SGC (2016) Valor nutricional de frutas nativas e exóticas do Brasil. Biosaúde, 18:82-95.

Oliveira LM, Silva AC, Pereira DMS, Lucchese AM \& Santana JFR (2013) Estabelecimento in vitro e crescimento inicial de Physalis angulata (Solanaceae). Sitientibus. Série Ciências Biológicas, 13: 1-6.
Oliveira LS, Dias PC \& Brondani GE (2013). Micropropagação de espécies florestais brasileiras. Pesquisa Florestal Brasileira, 33:439-453.

Oliveira-Cauduro Y, Lopes VR, De Bona CM, Alcantara GB \& Biasi LA (2016) Micropropagação de abacaxizeiro com enraizamento in vitro e ex vitro. Plant Cell Culture \& Micropropagation, 12:53-60.

Pasqual M (2001) Meios de cultura. $1^{\text {st }}$ ed. Lavras, UFLA. 74p.

Pinheiro CG, Lazarotto M, Muniz MFB, Redin CG \& Santos MV (2016) Efeito da assepsia superficial na germinação e incidência de fungos em sementes de espécies florestais. Pesquisa Brasileira Florestal, 36:253-260.

Poothong S \& Junnumsra I (2020) In vitro mineral nutrients and sucrose affecting growth and development of micropropagated red raspberry shoots. Thai Journal of Science and Technology, 9:119-128.

Silva DF, Strassburg RC \& Villa F (2015) Morfoanatomia do caule de espécies do gênero Physalis. Revista de Ciências Agroveterinárias, $14: 38-45$.

Tomazzi Y, Bonome LTS, Siqueira DJ, Moura GS \& Franzener GS (2019) Métodos de assepsia de sementes de feijão. Revista de Agroecologia e Desenvolvimento Sustentável, 14:229-237. 